\title{
Diskriminasi Ras dan Hak Asasi Manusia di Amerika Serikat: Studi Kasus Pembunuhan George Floyd
}

\section{Oktoviana Banda}

Program Studi Kajian Timur Tengah dan Islam Universitas Indonesia

Email : ovisargo@gmail.com

\begin{abstract}
Abstrak
Amerika Serikat memiliki sejarah kelam mengenai konflik rasial antara orang kulit putih dan orang kulit hitam selama kurang lebih tiga abad lamanya. Kasus yang terjadi terhadap orang kulit hitam bernama George Flyod di Amerika Serikat memiliki atensi yang sangat tinggi untuk masyarakat Amerika Serikat bahkan dunia. Hal tersebut dikarenakan orang kulit hitam sering kali menjadi korban tindakan diskriminatif orang kulit putih. Masyarakat kulit putih Amerika Serikat sulit untuk mengasimilasi orang kulit hitam, dikarenakan awal kedatangan orang kulit hitam ke Amerika Serikat hanya sebagai budak pekerja, sehingga terbentuk pola pikir mengenai orang kulit hitam sebagai warga negara kelas dua yang menjadi sebuah sikap dalam stratifikasi sosial di Amerika Serikat. Penelitian ini ingin menganalisis mengenai fenomena diskriminasi ras dan Hak Asasi Manusia (HAM) serta penyelesaian kasus hukum yang terjadi di Amerika Serikat. Berdasarkan kajian literatur dan analisis materi dari berbagai sumber ilmiah dapat disimpulkan bahwa Pemerintah Amerika Serikat sebagai penyelenggara negara juga ternyata masih menerapkan kebijakan diskriminatif, bahkan Amerika Serikat yang kita kenal sebagai pencetus dan pelopor HAM di dunia belum meratifikasi beberapa kebijakan hukum terkait penghapusan diskriminasi. Rasisme, diskriminasi ras, dan intoleransi merupakan ancaman serius terhadap kemajuan sosial masyarakat global.
\end{abstract}

Kata kunci : diskriminasi, hak asasi manusia, warga kulit hitam, Amerika Serikat

\section{Race Discrimination and Human Rights in the United States: Case Study of George Flyod Assassination}

\begin{abstract}
The United States had bad history of racial conflict between whites and blacks people for about three centuries. That happened to a black man named George Flyod in the United States has very high attention for the United States community and even people of around the world. This is because black people are often becomes victims of discriminatory acts by white people. White American society is difficult to assimilate black people, because the process enter of black people to the United States was only as slave labor, so that the mindset of black people as second-class citizens was formed which became an attitude in social stratification in the United States. This study aims to analyze the phenomenon of racial discrimination and human rights and the settlement of legal cases that occur in the United States. Based on literature review and material analysis from various scientific sources, it can be concluded that the United States Government as a state administrator is also still implementing discriminatory policies, even the United States, which we know as the originator and main pioneer of human rights in the world, has not ratified several legal policies related to the elimination of discrimination. Racism, racial discrimination and intolerance are serious threats to the social progress of the global community.
\end{abstract}

Keywords : discrimination, human rights, black citizens, United States 


\section{PENDAHULUAN}

Hak Asasi Manusia (HAM) adalah hak yang melekat pada setiap manusia, tanpa memandang ras, jenis kelamin, kebangsaan, suku, bahasa, agama, atau status lainnya. Hak asasi meliputi hak untuk hidup dan kebebasan. Kebebasan dari perbudakan dan penyiksaan, kebebasan berpendapat dan berekspresi, hak untuk bekerja dan memperoleh pendidikan, dan hak-hak dasar lainnya.

Hukum internasional mengenai HAM menjamin hak semua orang di seluruh negara, namun standar HAM umumnya tidak dapat ditegakkan di Amerika Serikat (AS) sehingga perlu diimplementasikan dalam bentuk hukum lokal, negara bagian, atau federal. Perjanjian internasional mencakup definisi hak-hak tersebut secara umum, sedangkan pengadilan internasional dan badan pengawas biasanya tidak memiliki kemampuan untuk secara langsung menegakkan keputusan mereka di AS. Salah satu cara terbaik untuk meningkatkan penerapan HAM di AS adalah dengan memperkuat perlindungan hukum domestik melalui penerbitan undang-undang yang mengakui keberadaan dan memastikan implementasi hak-hak tersebut oleh Pemerintah dan Pengadilan AS konsisten dengan standar internasional (Human Rights and United States Law, 2020). Peristiwa tanggal 25 Mei 2020 begitu fenomenal. Ketika petugas kepolisian (orang kulit putih) di wilayah Minneapolis menangkap seorang warga kulit hitam bernama George Floyd, seorang pria kulit hitam berusia 46 tahun. Penangkapan dilakukan setelah seorang karyawan toko menuduh Floyd membeli rokok dengan uang kertas $\$ 20$ palsu. Tujuh belas menit setelah mobil patroli pertama tiba di tempat kejadian, Floyd tidak sadarkan diri dan dijepit oleh tiga petugas polisi. Ia tidak menunjukkan tanda-tanda kehidupan.

The New York Times merekonstruksi kematian George Floyd dalam video berdurasi 8 menit 46 detik. Rekaman dari CCTV, video saksi di tempat kejadian perkara, dan dokumen resmi yang telah didapat menunjukkan bagaimana serangkaian tindakan oleh polisi berubah fatal. Video The New York Times menunjukkan para petugas mengambil serangkaian tindakan yang melanggar kebijakan Departemen Kepolisian Minneapolis, membuat Floyd tidak dapat bernapas, bahkan ketika ia dan para saksi meminta bantuan.

Kematian Floyd kemudian memicu demonstrasi di berbagai negara seperti Selandia Baru, dan Australia. Mereka menuntut keadilan terhadap pria kulit hitam tak bersenjata yang meninggal dalam penahanan tersebut. Selanjutnya, peristiwa ini memicu aksi dalam solidaritas dengan melakukan demonstrasi di AS, dan bersatu untuk mengutuk pembunuhan George Floyd.

Peristiwa tersebut memberikan tambahan bukti bahwa HAM belum diberlakukan secara merata di AS. Faktor ekonomi, hukum, pendidikan sosial, dan budaya tidak dipandang sebagai suatu hak. Kebijakan publik dapat mengecualikan hak seseorang dari kelayakan selama mereka tidak melakukan diskriminasi dengan alasan yang dilarang, misalnya ras. Meskipun penting untuk memastikan bahwa kebijakan publik tidak diskriminatif, namun kebijakan tersebut dimaksudkan untuk mengatasi permasalahan mendasar dari kegagalan untuk menjamin standar hidup yang memadai dan hak-hak lain yang diperlukan bagi semua orang di AS.

AS memiliki sejarah yang beragam mengenai bagaimana implementasi Hak Asasi Manusia. Meskipun AS menjadi negara yang mengawal pembentukan kebijakan mengenai HAM selama abad ke-20, namun tidak seperti banyak negara lain di dunia, AS belum meratifikasi sebagian besar perjanjian HAM di negaranya. Hal ini menjadi paradox yang terus terjadi hingga saat ini. Bahkan kebijakan luar negeri AS pun tidak selalu menghormati HAM. Selain itu pemerintah juga gagal melindungi HAM di dalam negeri, terutama hak ekonomi dan sosial.

Rasisme, dalam segala bentuk, adalah HAM yang kurang diakui sebagai permasalahan yang urgent untuk dicarikan solusinya saat ini khususnya di AS. Permasalahan ini ditentukan 
secara beragam, rasisme mengancam kehidupan dan hak jutaan orang di seluruh dunia. Meskipun melarang diskriminasi rasial melalui perjanjian multilateral pada tahun 1965, pemerintah AS masih melanggengkan dan mengizinkan rasisme dengan dukungan imunitas dan pembenaran bahwa tindakan-tindakan individual dari rasisme adalah hal yang biasa (Bradley, 2019). AS memberikan contoh yang kurang baik di tengah dunia, terlepas dari undang-undang antidiskriminasi dan hak perlindungan yang setara, pemerintah AS secara langsung telah gagal melindungi warganya dari perilaku rasisme. Polisi terus melakukan tindakan rasial dan membunuh orang Afrika-Amerika dengan tingkat yang sangat mengkhawatirkan sehingga memicu kemarahan publik.

\section{METODE PENELITIAN}

Metode penelitian ini menggunakan analisis deskriptif melalui pendekatan kualitatif dengan sumber data didapatkan melalui penelitian kepustakaan (library research). Rekonstruksi peristiwa yang terjadi atas kematian warga kulit hitam AS yang bernama George Floyd diperoleh dari beberapa sumber dan studi pustaka baik melalui artikel jurnal yang membahas tentang rasisme dan studi kasusnya maupun sumber berita mainstream.

Penelitian dilakukan dengan beberapa tahapan yaitu pertama, menyajikan pendahuluan yang menjelaskan latar belakang penelitian dan observasi awal untuk mengidentfifikasi permasalahan dan fenomena diskrimasi ras yang terjadi di AS. Dalam tahap pertama, peneliti melakukan rekonstruksi dengan mengumpulkan berbagai literatur terkait dengan isu rasisme dan HAM di AS, antara lain dari jurnal ilmiah, media massa yang banyak mengulas permasalahan isu rasisme dan HAM di AS. dan Kedua, menyusun kerangka konseptual sebagai dasar pembahasan dan menyusun fokus pembahasan terutama penyelesaian kasus hukum atas kematian George Floyd. Ketiga, menyusun kesimpulan atas teori konseptual dan pembahasan yang telah dipaparkan pada tahap kedua, serta menyusun rekomendasi terhadap pihak-pihak pemerhati HAM terutama yang terjadi di wilayah AS.

\section{HASIL DAN PEMBAHASAN}

Sejarah rasisme di AS telah mencatat berbagai masalah pelanggaran bersifat rasial sedari dulu hingga saat ini. Tak hanya kasus rasisme yang terjadi di masyarakat, sejarah rasisme di AS juga mencatat beberapa kasus pelanggaran rasial yang dilakukan oleh aparat kepolisian. Kasus rasisme telah berulang kali terjadi sehingga berdampak pada kesenjangan di bidang ekonomi, pendidikan, dan kesehatan di AS, terutama perlakuan diskriminatif antara warga kulit hitam dengan warga kulit putih.

Media massa berperan penting dalam mentransmisi informasi. Dalam era revolusi industri 4.0, pertumbuhan informasi dan teknologi terjadi sangat cepat. Berita tentang kasus kekerasan yang berujung pembunuhan George Flyod di AS menyulut rasa solidaritas dari seluruh penjuru dunia. Aksi protes yang terjadi dengan menumbuhkan kesan superioritas kulit putih dibanding warna kulit lain dengan slogan \#BlackLivesMatter menyebar dengan cepat melalui media massa. Dari sudut pandang media, rasisme memiliki makna prasangka kepada sekelompok tertentu yang terorganisir dalam masyarakat yang menganggap rasnya paling unggul. Dalam konstruksi masyarakat AS, rasisme merupakan pola berfikir yang memandang bahwa kelompok yang satu berbeda dengan kelompok yang lain. Sikap rasis ini tercermin dengan memberikan label kepada kelompok minoritas dan memberikannya diskriminasi sosial. Sikap sebagian warga AS ini terus mengalami pengulangan dan terjadi terus menerus dalam interaksi.

Rasisme sendiri dapat membangkitkan reaksi emosional yang sangat kuat, terutama bagi mereka yang telah merasakan penindasan dan eksploitasi yang berasal dari sikap dan perilaku rasis di negara AS. Untuk warga Afrika-Amerika, Asia-Amerika, penduduk asli Amerika, dan warga Latin (Hispanik), rasisme telah menciptakan sejarah sosial dibentuk oleh prasangka dan diskriminasi. Saat ini bahkan kegiatan rasis tersebut dimanifestasikan ke dalam bentuk intimidasi, kekerasan fisik, segregasi sosial-ekonomi, bahkan perusakan properti pribadi. 
Teori Sosiologi, memiliki pendekatan teoritis dan komprehensif yang mempelajari mengenai ras dan rasisme. Menurut Tanya Golash-Boza (2016), terdapat empat kondisi teori ras dalam kajian ilmu sosiologi yang mengarah pada teori ras dan rasisme yang kritis, yaitu (1) mampu menyatukan ras dan rasisme ke dalam kerangka analitis yang sama; (2) mampu menghubungkan teoritis ideologi rasis dengan struktur rasis; (3) menghapus penindasan rasial; (4) memasukkan analisis interseksional (titik temu). Menurutnya, teori ras modern terdiri dari dua proses yang saling berkaitan yaitu struktur rasis \& ideologi rasis. Dalam implementasinya, kedua proses tersebut saling berkaitan antara satu dengan yang lain hingga diekspresikan melalui sikap dan prasangka.

Diskriminasi ras bukanlah fenomena baru di AS, bahkan telah terjadi sejak ratusan tahun yang lalu. Stereotip masyarakat masih menganggap bahwa masyarakat kulit putih superior dan warga kulit hitam adalah pihak inferior, dan hal ini masih sulit dihilangkan hingga saat ini (Sutopo, 2016) (Lihat gambar 1).

Statistik yang disajikan oleh BBC (2020), terkait dengan kejadian penembakan sampai mati oleh polisi AS memperlihatkan bahwa warga Afrika-Amerika lebih besar kemungkinannya ditembak mati, terutama ketika dibandingkan dengan jumlah populasi mereka secara keseluruhan di AS.

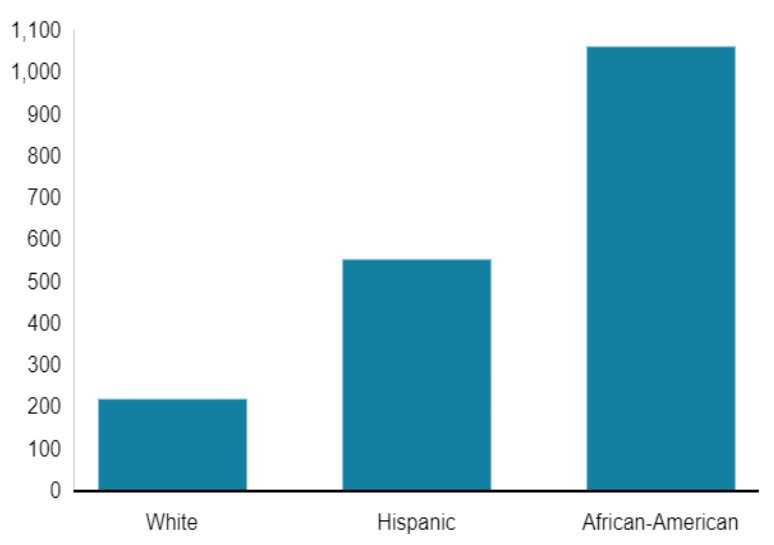

Gambar 1. Populasi Tahanan per 100,000 Orang Berdasarkan Ras Sumber: Biro Sensus AS, 2020
Faktanya, pada tahun 2019, sekalipun persentase warga Afrika-Amerika merupakan $14 \%$ dari keseluruhan populasi (menurut sensus resmi), jumlah mereka yang mati ditembak polisi lebih dari 23\% dari 1.000 kematian yang disebabkan oleh tembakan polisi. Dan angka ini relatif konsisten sejak tahun 2017, sedangkan angkanya pada populasi kulit putih justru menurun.

Keragaman ras dan etnis telah meningkat secara dramatis di AS sejak tahun 1980. Dengan meningkatnya imigran ke AS, tingkat fertilitas yang tinggi, struktur penduduk yang didominasi oleh usia muda, dan keunggulan demografis lainnya memicu kenaikan kaum minoritas sehingga orang kulit berwarna diproyeksikan akan melampaui jumlah ras kulit putih sebelum pertengahan abad (Colby, L.S \& Ortman, J.M., 2015). Kasus kematian George Floyd yang meninggal ketika ditangkap oleh polisi di AS, telah menjadi figur utama dalam demonstrasi menuntut kesetaraan dan keadilan bagi warga Afrika-Amerika dan tercatat menjadi aksi protes menentang rasisme terbesar sejak tahun 1960an. Kasus yang menimpa George Floyd pada 25 Mei 2020 lalu menjadi salah satu potret buram panjang dalam sejarah rasisme di AS yang berakhir tragis.

Kota Minneapolis tempat insiden terbunuhnya George Floyd menjadi salah satu saksi bisu sejarah rasisme di AS. Kota Minneapolis dihuni oleh warga dengan ras dan kulturnya yang cukup beragam. Kota ini kerap kali disebut sebagai sebuah kota yang layak berbangga atas keberhasilannya dalam menyemai multikulturalisme. Namun faktanya, kota Minneapolis perlu berjuang mengatasi pemisahan dan kesenjangan ras terutama di bidang pendidikan dan kesehatan yang masih terjadi.

Kajian dari organisasi non pemerintah bernama Mapping Police Violence (BBC, 2020) menyatakan bahwa orang kulit hitam berpeluang tiga kali lipat lebih besar untuk terbunuh oleh polisi daripada orang kulit putih. Ketegangan rasial di Minneapolis memang telah berlangsung lama. Pada tahun 2019, Minneapolis menjadi 
wilayah metro terburuk keempat di AS untuk warga kulit hitam Amerika, dan kota ini sangat tersegregasi. Berdasarkan informasi yang diperoleh melalui website national geographic (2020) menunjukkan bahwa tuduhan rasisme polisi juga menjadi masalah yang konsisten yang terjadi di kota ini.

Kasus sebelumnya yang juga mengusung tema rasisme, sebelum meluasnya informasi mengenai kasus kematian George Floyd adalah kasus kematian Breonna Taylor yang meninggal dunia di usia 26 tahun pada bulan Maret 2020 lalu di Louisville, Kentucky. Rumahnya didatangi polisi secara tiba-tiba dalam sebuah misi penyergapan narkoba. Setelah rumahnya diperiksa, polisi tidak menemukan satupun obatobatan terlarang sebagaimana dituduhkan. Akan tetapi sang pemilik rumah, Breonna Taylor terbunuh dalam proses penyergapan misterius tersebut. Media lokal melaporkan bahwa polisi telah melakukan aksi penggeledahan, tanpa adanya peringatan terlebih dulu. Berdasarkan informasi selanjutnya, diperoleh pernyataan bahwa kepolisian setempat mendatangi alamat yang salah dan menyebabkan kematian bagi Breonna Taylor.

Kasus rasisme bukan fenomena yang baru saja mengemuka di permukaan negara AS. Pada tanggal 24 Desember 1865 pernah berdiri organisasi yang disebut dengan Ku Klux Klan (KKK) atau dikenal sebagai 'The Klan' yaitu sebuah kelompok rasis ekstrem di AS. Sejarah gerakan supremasi dan superioritas dari ras kulit putih di AS tak lepas dari gerakan kelompok ini. Organisasi rasis ini dibentuk setahun setelah berakhirnya perang sipil. Kelompok ini berkeyakinan bahwa ras kulit putih adalah ras terbaik dibandingkan dengan ras lain yang ada di AS. Mereka mendirikan organisasi tersebut dengan maksud untuk berjuang memberantas kaum kulit hitam dan kaum minoritas di AS seperti Yahudi, Katolik, homoseksual, Asia, dan imigran. Empat tahun setelah berdiri, pemerintah mengumumkan bahwa organisasi ini ilegal. Namun demikian, organisasi tersebut masih beroperasi dan tetap menjalankan aksi pembunuhannya terhadap warga kulit hitam dan kaum minoritas lain. Bahkan, kelompok ini juga menyerang warga kulit putih yang dianggap sebagai pelindung bagi warga kulit hitam.

Aksi Ku Klux Klan memuncak pada era tahun 1950-1960an yang pada akhirnya memunculkan beberapa kelompok perlawanan dari kalangan kulit hitam AS dan tokoh-tokoh yang menyerukan persamaan hak dan anti rasisme seperti Malcolm X dan Martin Luther King. Namun demikian, hingga kini pemerintah AS dianggap masih belum pernah melakukan usaha serius untuk memberantas kelompok yang dikategorikan berbahaya ini.

Sampai dengan ini, isu-isu keadilan dan rasisme masih mengakar dihampir seluruh aspek kehidupan masyarakat AS. Negara AS yang dikenal sebagai negara adidaya dengan segala kekuatan politik dan ekonominya, seolah tidak berdaya menghadapi fakta justifikasi yang mempertahankan superioritas warga kulit putih. Berikut adalah paparan dan ilustrasi mengenai kondisi termarginalkan kepentingan warga kulit hitam dibandingkan warga kulit putih, yang tercermin pada aspek sosial-budaya, pendidikan, hukum, ekonomi dan politik.

Kecenderungan dalam diversifikasi masyarakat tersebut bisa sangat berdampak sampai dengan level negara. Sebagai contoh, keberagaman telah mendorong kecenderungan kaum minoritas untuk mendukung Partai Demokrat di negara bagian, dan mungkin memiliki dampak yang lebih besar di masa depan karena lebih banyak Hispanik dan Asia memiliki hak pilih (Frey, 2015).

\section{Aspek Sosial-Budaya}

Pada tahun 1950, UNESCO menyatakan bahwa seluruh manusia di muka bumi ini adalah sama yaitu sebagai homo sapiens yang terdiri dari sejumlah populasi, dan populasi yang terbesar adalah ras. Tidak ditemukan bukti ilmiah yang menyatakan bahwa adanya korelasi antara intelektual dengan perbedaan ras secara biologis. Hal ini menjadi dasar bahwa tidak terdapat bukti ilmiah yang dapat menempatkan hierarki ras tertentu lebih unggul dibandingkan dengan ras yang lain. Namun fakta yang terjadi sampai saat ini adalah suatu kontruksi sosial yang menempatkan ras tertentu (warga kulit putih) lebih unggul dibandingkan dengan ras 
kulit lain (warga kulit hitam). Keyakinan itu kemudian mendorong sebagian masyarakat tersebut untuk mendominasi dan menguasai masyarakat ras yang dianggap lebih rendah (AlHafizh, 2016). Diskriminasi pada aspek sosialbudaya dalam masyarakat pascakolonial di AS membentuk pola perilaku masyarakat dalam aktivitas kehidupan sehari-hari seperti bentuk penghindaran (avoidance), pengucilan (exclusion), diskriminasi secara fisik (physical abuse) bahkan ke dalam bentuk menciptakan kepunahan suatu ras (extinction).

Bentuk diskriminasi yang diperlihatkan adalah segregasi yang dilakukan oleh warga ras kulit putih terhadap warga kulit hitam dengan menonjolkan perbedaan fisik dan biologis secara terbuka, yang kemudian menciptakan pandangan bahwa status sosial warga kulit hitam lebih rendah, inferior, minoritas dan terbelakang. Oposisis biner menjadi hal yang lumrah. Hal ini menciptakan klaster wilayah yang memisahkan antara wilayah yang dominasi kulit hitam dan wilayah yang didominasi kulit putih, sehingga dari struktur sosial terjadi jurang pemisah diantara dua ras tersebut.

Wilayah Afrika-Amerika atau wilayah hitam adalah jenis kantong ras kulit hitam yang ditemukan di beberapa kota di AS yang mayoritas populasinya adalah warga kulit hitam yang biasa dikenal dengan sebutan ghetto atau pemukiman kumuh. Pembentukan wilayah ini berkaitan dengan sejarah pemisahan di AS, baik sebagai bentuk produk hukum formal maupun yang terbentuk akibat sentimen sosial di kalangan masyarakat. Aspek sosial-budaya juga erat kaitannya dengan asumsi dan cara berpikir (mindset) masyarakat pada umumnya terkait dengan perbedaan ras. Fenomena kulit hitam selalu disandingkan dan dilabelkan oleh masyarakat kulit putih dekat dengan aksi kriminalitas dan aktivitas kejahatan, sehingga harus ada segregasi wilayah yang jelas untuk memberikan keterbatasan ruang gerak warga kulit hitam sehingga tidak dapat mengancam kehidupan masyarakat kulit putih. Tabel 1 memperlihatkan komposisi negara bagian di AS yang memiliki populasi Afrika-Amerika.

\begin{tabular}{clcr} 
Peringkat & \multicolumn{1}{c}{ Kota } & Populasi & Persentase \\
\hline 1 & $\begin{array}{l}\text { Detroit, } \\
\text { Michigan }\end{array}$ & 713.777 & $84,3 \%$ \\
\hline 2 & $\begin{array}{l}\text { Jackson, } \\
\text { Missisippi }\end{array}$ & 173,514 & $80,1 \%$ \\
\hline 3 & $\begin{array}{l}\text { Miami } \\
\text { Gardens, } \\
\text { Florida }\end{array}$ & 107,167 & $77,9 \%$ \\
& Birmingham, \\
& Alabama \\
\hline 4 & $\begin{array}{l}\text { Baltimore, } \\
\text { Maryland }\end{array}$ & 620,961 & $65,1 \%$ \\
\hline 5 & $\begin{array}{l}\text { Memphis, } \\
\text { Tennessee }\end{array}$ & 646,889 & $64,1 \%$ \\
\hline 7 & $\begin{array}{l}\text { NewOrleans, } \\
\text { Louisiana }\end{array}$ & 343,831 & $61,2 \%$ \\
\hline 8 & $\begin{array}{l}\text { Flint, } \\
\text { Michigan }\end{array}$ & 102,434 & $59,5 \%$ \\
\hline 9 & $\begin{array}{l}\text { Montgomery } \\
\text { Alabama }\end{array}$ & 205,764 & $57,4 \%$ \\
\hline 10 & $\begin{array}{l}\text { Savannah, } \\
\text { Georgia }\end{array}$ & 136,286 & $56,7 \%$ \\
\hline
\end{tabular}

Tabel 1. Kota yang Memiliki Populasi AfrikaAmerika Tertinggi (Sensus 2010) Sumber: Biro Sensus AS, 2011

Dalam aspek sosial-budaya kontemporer, keyakinan akan keunggulan ras tertentu semakin diperkuat dan terus diinternalisasikan melalui karya sastra atau tulisan yang bersifat terselubung dan seolah-olah tidak rasis. Diskriminasi di dunia modern tidak dinyatakan secara terang-terangan karena akan menghadapi masalah hukum dan melanggar undang-undang, sehingga bentuk baru sebuah model rasis adalah bersifat implisit. Salah satu yang jenis karya sastra yang mengangkat isu rasisme di tengah kehidupan sosial masyarakat adalah karya sastra black writing. Karya sastra ini mempertemukan penulis kulit hitam dan kulit putih dalam gagasan yang sama mengenai yaitu tema isu-isu perbedaan ras dan rasisme salah satunya adalah karya novelis Jacqueline Woodson yang menampilkan isu-isu perbedaan ras lewat sebuah karya sastra (Al-Hafizh, 2016). Selain dalam bentuk karya sastra, pada aspek sosial-budaya juga dapat dimunculkan pada karya-karya visual berupa film yang menampilkan suasana yang jauh lebih hidup karena beberapa karya film tersebut berhasil diangkat dari sejarah kisah nyata. 
Salah satu film yang mengisahkan tentang isu rasisme di AS adalah film The Butler yang mengangkat cerita tentang black American. Film tersebut terilhami dari kisah nyata mengenai seorang kepala pelayan presiden AS yang bekerja selama kurang lebih 34 tahun di gedung putih sejak tahun 1950an disaat pergerakan HAM baru mulai digalakkan. Film tersebut juga menceritakan sejarah kelam kehidupan kaum kulit hitam dari masa ke masa dengan sudut pandang seorang kepala pelayan presiden AS yang berkulit hitam, yang juga menerima perlakuan rasisme dan diskriminasi. Hal ini menjadi sangat ironi mengingat posisinya yang berada dekat dengan penguasa nomor satu di AS, seperti diskriminasi upah yang diterima secara berbeda antara pelayan kaum kulit putih dengan pelayan yang berasal dari kaum kulit hitam.

Beberapa contoh kasus-kasus di bawah ini kembali menegaskan bahwa AS di satu sisi sebagai pelopor HAM tetapi di sisi lain secara faktual diskriminasi atas nama ras banyak terjadi sejak lama ini di AS:

1. Kasus John Casor

Kasus ini terjadi sekitar tahun 1654-1655. Casor adalah orang pertama yang secara sewenang-wenang dinyatakan sebagai budak seumur hidup di AS (kasus sebelumnya telah berakhir dengan seorang pria bernama John Punch dinyatakan sebagai budak seumur hidup sebagai hukuman karena mencoba melarikan diri dari perbudakan kontraknya, ia dibunuh. Sedangkan budak berkulit putih, tidak dihukum dengan cara ini.

Penelitian yang dilakukan Universitas Wesleyan, budak, biasanya ditangkap dan dijual oleh suku-suku Afrika lainnya, diangkut melintasi Atlantik ke Amerika. Kisah Casor sangat suram di belakang. Tergelincirnya dia ke dalam perbudakan diikuti oleh banyak orang keturunan Afrika yang diperlakukan sebagai properti di AS. Itu adalah momen penting dalam sejarah perbudakan institusional.
2. Kuburan massal dan pembantaian ras kulit hitam di Tulsa, Oklahoma, AS

Kisah ini adalah kasus rasial terbesar dalam sejarah AS, yaitu pembantaian ras kulit hitam di Tulsa Terjadi pada tahun 1921. Pembantaian dilakukan oleh gerombolan kulit putih yang membakar gedung-gedung komersial dan rumah-rumah di Greenwood, yang merupakan tempat tinggal komunitas kulit hitam. Peristiwa ini dikenal juga sebagai Black Wall Street. Menurut Tulsa Historical Society, ada 300 orang yang terbunuh pada hari itu, dan kebanyakan adalah orang kulit hitam.

Akar konflik bermula terjadi di dalam lift Gedung Drexel di Third and Main, Tulsa, Oklahoma, ketika seorang pria ras kulit hitam bernama Rowland memegang lengan seorang gadis berkulit putih bernama Sarah Pages yang merupakan operator lift. Insiden Sarah-Rowland di dalam lift terjadi pada pada Senin pagi, 30 Mei 1921. Polisi Tulsa menangkap Rowland keesokan harinya untuk dimintai keterangan. Rowland kemudian didakwa menyerang perempuan dan kasusnya dibawa ke pengadilan.

Sejarawan Rachael Hill dalam "Tulsa Massacre 1921", dimuat dalam San Francisco State University History Student Journal, Volume XVIII, menyebut orang kulit hitam Tulsa punya banyak alasan untuk percaya bahwa Rowland dihukum mati setelah ditangkap. Dalam Laporannya, Komisi Oklahoma mencatat adanya rasisme yang kuat dan kekerasan pada kulit hitam yang dianggap lazim atau disetujui secara sosial.

Di awal abad ke-20, orang kulit hitam Amerika kerap menyaksikan kaumnya dihukum mati tanpa pengadilan. Kondisi ini terus terjadi dan dianggap sebagai "hukum tidak tertulis" yang memungkinkan untuk membunuh orang tanpa tuduhan di bawah sumpah, tanpa diadili oleh juri, tanpa kesempatan untuk membela diri, dan tanpa hak mengajukan banding. 


\section{Kerusuhan Rodney King}

Kasus ini dikenal juga dengan Kerusuhan Los Angeles terjadi tahun 1992. Serangkaian kerusuhan, penjarahan, pembakaran dan kekacauan sipil. Kerusuhan ini dipicu ketika dewan juri pengadilan membebaskan empat petugas kepolisian Los Angeles dari aksi kebrutalan polisi atas pemukulan terhadp Rodney King, seorang buruh bangunan yang diduga meminum alkohol PCP ketika mengemudi, tapi hasil pemeriksaan di rumah sakit Rodney King negatif PCP.

4. Tekanan sosial memicu penyakit mental

Banyak warga kulit hitam AS yang sejak kecil hingga dewasa hidup dalam tekanan diskriminasi ras ini, memicu mereka melakukan penyimpangan psikologi Body Dysmorpchic Disorder (BDD). Hal ini dialami oleh Raja Pop dunia yaitu Michael Jackson yang melakukan operasi plastik, merubah warna kulit hitam menjadi kulit putih. Selain itu ada juga penyanyi rapper wanita era 90an, bernama Lil' Kim yang mengalami BDD dan melakukan operasi plastik merubah warna kulit.

\section{Aspek Pendidikan}

Diskriminasi dan rasisme masih saja mewarnai pendidikan di AS. Akses untuk mendapatkan pendidikan yang layak, terutama untuk tingkat pendidikan tinggi masih terbatas bagi warga kulit hitam. Hal ini tercermin dari sejumlah universitas yang mau menerima mahasiswa keturunan warga Afrika-Amerika dinilai masih sangat terbatas. Salah satu cara utama agar mahasiswa kulit hitam dapat memperoleh pendidikan tinggi yang layak dengan mendirikan universitas sendiri (National geographic, 2019). Universitas yang dikenal sebagai perguruan tinggi khusus mahasiswa kulit hitam adalah konsorsium Pusat Universitas Atlanta, yaitu universitas yang terdiri dari empat perguruan tinggi yaitu Universitas Clark Atlanta, Spelman College, Morehouse College dan Morehouse School of Medicine yang berlokasi di Atlanta, Georgia yang berlokasi secara berdekatan.

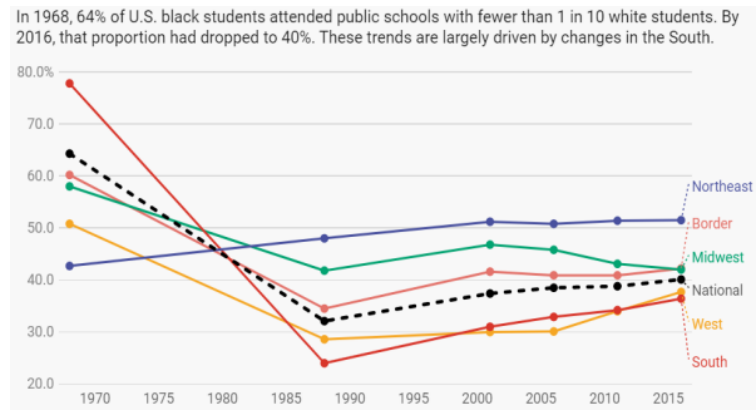

Gambar 2. Siswa Keturunan Afrika-Amerika di Sekolah Umum Non Kulit Putih Sumber: (The Civil right Project, www.truthout.org, 2020)

Diskriminasi dalam sistem pendidikan juga tercermin pada level pendidikan yang lebih rendah atau sekolah dasar dan menengah. Meskipun angka persentase keberadaan dan pendaftaran bagi siswa kulit hitam pada sekolah publik (education segregation) mengalami peningkatan di setiap tahun, namun pemisahan pendidikan masih mewarnai sistem pendidikan di AS. Kondisi segregasi dalam pola pendidikan ini berbeda di tiap wilayah negara bagian AS (Lihat Gambar 2)

Kota New York memiliki beberapa sekolah yang paling terpisah di negara AS. Siswa berkulit hitam dan latin masih sangat kurang terwakili di sekolah-sekolah umum tingkat menengah di AS (truthout.org, 2020). Hampir $40 \%$ siswa Afrika-Amerika menempuh pendidikan di sekolah publik yang juga didominasi oleh murid Afrika-Amerika, jumlah ini telah banyak berkurang dibandingkan dengan kondisi pendidikan pada tahun 1968 yang mencatat angka 68\%. Faktanya adalah tiga perempat siswa kulit hitam belajar di sekolah yang lebih dari 50\% muridnya non kulit putih. Hal ini masih menggambarkan bahwa masih terdapat pemisahan (rasial dan diskriminasi) dalam sistem pendidikan AS.

Beberapa contoh kasus nyata diskriminasi ras yang terjadi di bidang pendidikan AS, bisa kita lihat dalam ulasan berikut:

1. Perbedaan Tarif dan Dana Pendidikan

Sejak tahun 1960an sebagian besar siswa Afrika-Amerika, Latino, dan penduduk asli Amerika (suku Indian) dididik di sekolah- 
sekolah yang sepenuhnya terpisah yang didanai dengan tarif beberapa kali lebih rendah daripada mereka yang melayani orang kulit putih dan dikeluarkan dari banyak lembaga pendidikan tinggi seluruhnya. Akhir dari segregasi hukum diikuti oleh upaya untuk menyamakan pengeluaran sejak tahun 1970 telah membuat perbedaan besar untuk prestasi siswa. Pada setiap tes nasional besar, termasuk Penilaian Nasional Kemajuan Pendidikan, kesenjangan dalam skor tes siswa minoritas dan kulit putih menyempit secara substansial antara tahun 1970 dan 1990, terutama untuk siswa sekolah dasar. Pada Scholastic Aptitude Test (SAT), skor siswa Afrika-Amerika naik 54 poin antara 1976 dan 1994, sementara siswa kulit putih tetap stabil.

2. Kebijakan Disiplin "Zero Tolerance" di sekolah

Pada tahun 2001, American Bar Association (ABA) mendukung penghapusan undang-undang tanpa toleransi di sekolahsekolah. Hampir 90\% sekolah negeri di AS menerapkan kebijakan tanpa toleransi, dan bukti menunjukkan bahwa kebijakan seperti itu kemungkinan besar akan diadopsi di distrik-distrik di mana mayoritas badan siswa adalah orang Amerika keturunan Afrika dan / atau orang Latin.

Dalam sebuah studi yang representatif secara nasional yang dilakukan oleh Education Insights di Agenda Publik, 19\% siswa kulit putih, 26\% siswa Hispanik, dan $33 \%$ siswa kulit hitam melaporkan bahwa sekolah mereka tidak konsisten dalam menerapkan disiplin. Menurut data Departemen Pendidikan A.S., siswa AfrikaAmerika menyumbang $17 \%$ dari semua siswa yang terdaftar di sekolah umum, namun merupakan $32 \%$ dari semua siswa yang menerima penangguhan di luar sekolah. Remaja kulit putih merupakan $63 \%$ dari pendaftar sekolah umum, tetapi hanya 50\% dari mereka yang diskors atau diusir.

3. Sistem Pelacakan Akademik

Setiap distrik di AS telah membuat program pelacakan akademik. Program yang memungkinkan guru dan administrator sekolah untuk menentukan kemampuan dan potensi siswa dan kemudian menempatkan siswa tersebut di jalur akademik yang mencerminkan persepsi pribadi guru atau administrator. Jalur akademis berkisar dari program perbaikan dan pendidikan khusus hingga program yang dipercepat dan berbakat. Studi menunjukkan bahwa siswa Afrika-Amerika dan Latin terlalu banyak terwakili di jalur yang lebih rendah dan kurang terwakili di jalur yang lebih tinggi.

Pelacakan dapat dimulai sangat awal dalam karier akademik anak dan dapat sangat merusak masa depan anak. Jika seorang anak ditempatkan di jalur yang lebih rendah karena dianggap tidak mampu melakukan pekerjaan umum, seringkali sangat sulit bagi anak tersebut untuk masuk ke jalur yang lebih tinggi karena sifat alami dari sistem pelacakan.

\section{Aspek Hukum}

Gerakan hak-hak sipil yang mengusung adanya kesetaraan hukum bagi semua warga AS tanpa melihat perbedaan dalam aspek biologis dan fisik telah lama diperjuangkan. Gerakan ini bertujuan untuk mengakhiri sikap diskriminasi terutama bagi warga Afrika-Amerika dan warga minoritas lain untuk menuntut adanya kesetaraan di mata hukum.

Berdasarkan data yang ditunjukkan oleh (www.mappingpoliceviolence.org, 2020) tiga negara bagian di AS memiliki tingkat pembunuhan orang kulit hitam oleh petugas polisi tertinggi yaitu California, Texas dan Florida. Berdasarkan sumber yang sama, data tersebut mencerminkan angka kematian yang tinggi bagi warga kulit hitam untuk dibunuh oleh petugas polisi hampir merata seluruh negara bagian AS. Di Utah, orang AfrikaAmerika hanya terdiri dari 1,06 persen dari populasi, tetapi polisi bertanggung jawab atas 10 persen pembunuhan selama tujuh tahun terakhir atau 9,21 kali angka kematian warga kulit putih. Di Minnesota, orang kulit hitam Amerika hampir empat kali lebih berisiko terbunuh oleh penegak hukum, meskipun populasi hanya terdiri dari 5 persen dari keseluruhan populasi. 

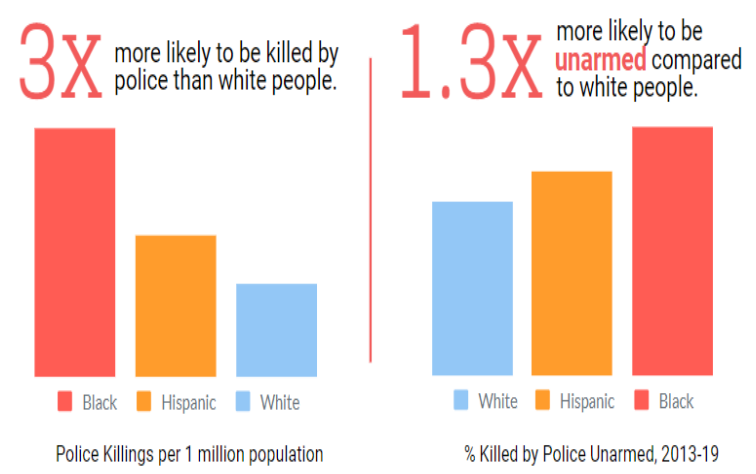

Gambar 3. Ilustrasi Tingkat Kematian Warga Kulit Hitam oleh Oknum Polisi

Sumber: www.mappingpoliceviolence.org, 2020

Dari data diatas, juga menunjukkan sebanyak $47 \%$ penduduk yang tidak bersenjata terbunuh oleh 100 Departemen Kepolisian Kota terbesar di AS adalah warga kulit hitam. Departemen kepolisian ini membunuh orang kulit hitam yang tidak bersenjata 4 kali lebih tinggi dibandingkan terhadap warga kulit putih yang tidak bersenjata. Hanya 1 dari 100 Departemen Kepolisian Kota terbesar di AS yang tidak membunuh siapa pun sejak Januari 2013 s.d Desember 2019 yaitu Departemen Kepolisian Kota Irvine di California.

Diketahui bahwa sepanjang tahun 20132019 ada sebanyak 99\% kasus kematian warga kulit hitam yang tidak dapat terselesaikan sampai dengan saat ini dan hanya sebanyak $1 \%$ kasus yang dapat berakhir dengan putusan bersalah kepada pihak oknum polisi yang melakukan tindak pembunuhan (Lihat gambar 4)

Contoh kasus fakta diskriminasi ras yang terjadi daam penegakan hukum menurut data The National Association for the Advancement of Colored People (NAACP) yaitu organisasi yang memperjuangkan hak-hak kulit hitam AS, jumlah warga kulit putih yang menggunakan narkoba lima kali lipat lebih banyak ketimbang warga kulit hitam. Namun warga AfrikaAmerika yang didakwa terkait narkoba berjumlah 10 kali lipat lebih banyak ketimbang warga kulit putih. Hal ini membuktikan bahwa dari aspek hukum, masih belum adanya pemerataan keadilan dan potensi rasis masih sering terjadi (Welle, 2020).

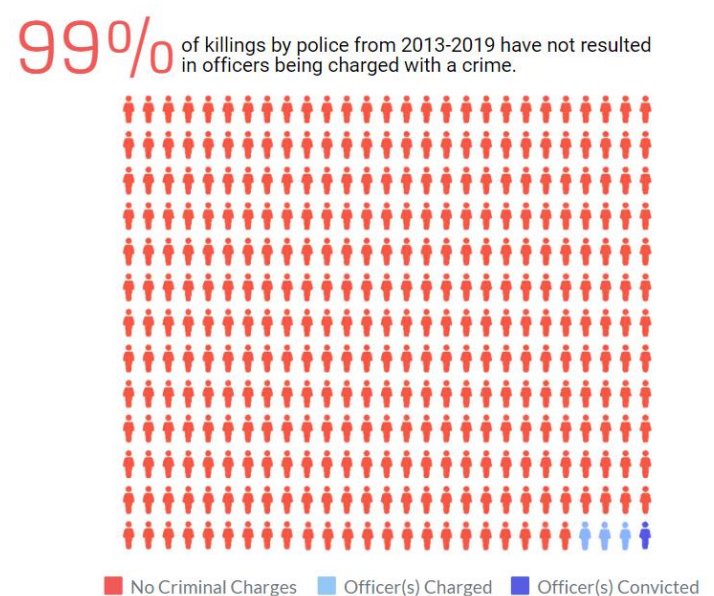

Gambar 4. Penyelesaian Kasus Kematian Warga

Kulit Hitam yang Dilakukan Oknum Polisi Sumber: www.mappingpoliceviolence.org, 2020

Selain itu, kasus penegakan hukum di penjara Guantanamo juga menjadi catatan sejarah kelam pelanggaran HAM. Banyak terpidana kasus penyelundupan, narkoba, pembunuhan yang mayoritas adalah orang berkulit hitam dibawa ke teluk Guantanamo. Penjara Guantanamo layaknya penjara seumur hidup bagi warga kulit hitam, dan dalam penegakkan hukum polisi melakukan interogasi dan intimidasi hingga pembunuhan dalam mencari fakta.

\section{Aspek Ekonomi}

Pada aspek ekonomi, diskriminasi dan persoalan rasisme begitu terlihat di AS dan menjadi sebuah kegagalan terburuk dari sebuah negara adidaya yang mengusung ekonomi liberal dan kebebasan sehingga menjadi sorotan dunia internasional. Rasisme yang terjadi di AS merupakan sebuah representasi dari segala bentuk aktivitas brutal baik yang dapat dengan jelas terlihat maupun tidak terlihat (implisit). Tingkat pengangguran yang tinggi di antara masyarakat kulit hitam dan keturunan Hispanik menjadi kunci dari perlambatan ekonomi di negara tersebut (CNBC Indonesia, 2020). Hal ini dikarenakan, tidak semua orang memiliki peluang yang sama untuk dapat memiliki akses terhadap ekonomi inklusif menyebabkan perlambatan pada ekonomi secara keseluruhan. Kelompok masyarakat kulit hitam dan warga keturunan merupakan kelompok dengan 
pertumbuhan demografis terbesar di AS yang dapat menyebabkan perekonomian tumbuh lebih lambat apabila tidak ada partisipasi dan dukungan dari kelompok tersebut.

Warga kulit hitam pada umumnya dekat dengan fenomena kemiskinan dan pengangguran serta memiliki standar pendidikan yang relatif lebih rendah sehingga menyebabkan orang kulit hitam lebih sulit mendapatkan pekerjaan yang layak. Dengan sulitnya mendapatkan pekerjaan yang layak menyebabkan pendapatan atau penghasilan yang diterima kurang mencukupi kebutuhan hidup dasar yang pada akhirnya dapat menjadi penyebab tingginya kasus sosial seperti pengangguran dan kejahatan di kalangan warga kulit hitam. Siklus kehidupan ekonomi tersebut menjadi stigma umum di tengah masyarakat Afrika-Amerika.

Pada umumnya pekerjaan yang biasa dilakukan oleh warga Afrika-Amerika adalah pekerjaan kasar dan buruh. Menurut data biro sensus AS, rata-rata penghasilan warga AfrikaAmerika hanya tiga perlima dari penghasilan dari waga kulit putih non Hispanik. Pada tahun 2018, rata-rata penghasilan warga AfrikaAmerika tercatat sebesar $\$ 41.400$ jauh lebih rendah dibandingkan warga kulit putih yang pendapatannya menyentuh nominal $\$ 70.600$ (CNBC Indonesia, 2020). Kesenjangan tersebut terus terjadi karena warga kulit hitam lebih banyak menjadi pekerja yang membutuhkan keterampilan rendah karena hanya memiliki tingkat pendidikan yang juga rendah.

Berdasarkan survei yang dilakukan oleh Federal Reserve Board pada tahun 2017, median (nilai tengah) kekayaan orang AfrikaAmerika hanya satu persepuluh dari warga kulit putih non-Hispanik yaitu $\$ 17.600$ berbanding \$171.000. Menurut data Pusat Pengendalian dan Pencegahan Penyakit (Center for Desease Control and Prevention) orang Afrika-Amerika berusia 18 hingga 49 tahun dua kali lebih mungkin meninggal akibat penyakit jantung dibandingkan orang kulit putih, fenomena ini ditambah dengan kondisi $12,2 \%$ warga AfrikaAmerika yang tidak memiliki asuransi kesehatan (CNBC Indonesia, 2020). Dengan segala keterbatasan dari aspek ekonomi menyebabkan tingkat kematian warga Afrika-Amerika tercatat cukup tinggi di AS. Fenomena tempat tinggal yang berada di pinggiran kota dengan kondisi sanitasi yang buruk, pendidikan yang rendah sehingga memiliki keterbatasan untuk memperoleh pekerjaan yang layak dan tingkat kesehatan yang rendah menjadi penyebab tingginya angka kematian bagi warga AfrikaAmerika di AS.

\section{Aspek Politik}

Dalam bidang politik diskriminasi ras juga terjadi. Hal tersebut adalah efek domino dari diskriminasi di bidang-bidang sebelum. Kebodohan dan kemiskinan struktural di AS memperparah kesempatan berpolitik. Namun di tahun 1990an, dengan menguatnya isu demokrasi dan kebangkitan Partai Demokrat dibanding Partai Republik yang konservatif membawa pengaruh positif pada kesamaan kesempatan politik bagi warga kulit hitam di AS. Keterwakilan kulit hitam di parlemen AS juga membuka jalan kesempatan aspirasi kaum kulit hitam diperjuangkan di level politik.

Hasil dari perubahan politik disana, Barack Obama menjadi Presiden AS ke-44 yang merupakan presiden pertama AS yang berasal dari keturunan warga Afrika-Amerika (kulit hitam) menjabat sejak Januari 2009 - Januari 2017. Dengan terpilihnya Barack Obama sebagai presiden tersebut, warga AfrikaAmerika menyatakan bahwa AS telah memasuki era pascarasial (post racial) dan berharap kondisi yang lebih baik ke depan. Namun ternyata fakta di lapangan membuktikan hal yang berbeda. Praktek rasial dan diskriminasi masih mewarnai hampir seluruh aspek kehidupan masyarakat di AS, temasuk di bidang politik.

Tahun 2020 menandai seratus tahun Amandemen ke-19 dan peringatan satu abad ke Amandemen Kelimabelas (1870) yaitu hak suara dalam pemilihan bagi orang Afrika-Amerika setelah Perang Saudara. Hal tersebut merupakan perjuangan berkelanjutan dari pihak laki-laki kulit hitam dan perempuan kulit hitam untuk memiliki hak sebagai pemilih. Sampai dengan pertengahan tahun 1960-an, warga Afrika- 
Amerika berkampanye mengenai pentingnya memiliki hak untuk mengikuti pemilihan, dan perjuangan untuk menuntut hak tersebut masih terus berlanjut di pengadilan hingga hari ini. Tema mengenai hak suara juga mencakup adanya kesempatan yang sama bagi warga kulit hitam untuk terpilih dan diangkat sebagai pejabat di tingkat lokal dan/atau nasional (The Association for the Study of African American Life and History/ASALH, 2019). Kampanye juga menuntut adanya legislasi hak yang setara dan kesempatan yang sama bagi warga kulit hitam untuk aktif dalam partai politik

\section{PENUTUP}

Berdasarkan paparan dan pembahasan dapat ditarik kesimpulan bahwa fenomena kasus pembunuhan George Floyd yang memicu demonstrasi besar-besaran di AS bukan terjadi secara otomatis dan bukan hal baru yang terjadi di AS. Kasus George Floyd merupakan luapan pencetus yang menyatakan bahwa selama ini secara kultur masyarakat AS terbelah menjadi dua ras yaitu ras kulit hitam dan ras kulit berwarna (terutama warga Afrika-Amerika). Secara sosial, masyarakat AS menanggapi perbedaan ras itu dengan sikap diskriminatif dan segregatif.

Pemerintah AS sebagai penyelenggara negara ternyata masih menerapkan kebijakan diskriminatif, bahkan AS yang dikenal sebagai pencetus dan pelopor HAM di dunia belum meratifikasi beberapa kebijakan hukum terkait penghapusan diskriminasi. AS juga belum meratifikasi sebagian besar perjanjian HAM di negaranya. Kebijakan luar negeri AS pun tidak selalu menghormati HAM. Selain itu pemerintah juga gagal melindungi HAM di dalam negeri, terutama hak ekonomi, sosial, pendidikan dan penegakan hukum serta politik.Hal ini perlu langkah tegas bahwa tugas seorang polisi wajib memperhatikan HAM seperti amanat Deklarasi UDHR, Bill of Rights dan konstitusi hukum AS. Sehingga AS tidak hanya negara yang secara tesktual memperjuangkan HAM, tetapi juga secara faktual nyata menjalankan nilai-nilai HAM dalam kehidupan masyarakat sehari-hari.
Saat ini, kesadaran demokrasi yang tinggi, di AS pun lebih demokratis dan masyarakat sipil disana (kulit putih) juga mulai sadar menolak rasisme. Masyarakat dunia pun mulai demoratis. Kondisi ini juga adalah peluang untuk menghentikan rasisme di AS. Negara dan organisasi dunia, seperti Dewan HAM PBB, maupun lembaga Internasional Non-Government Organization (INGO), media massa independen (yang bebas kepentingan) juga dapat mengontrol rasisme dan penegakan HAM secara nyata di AS.

\section{DAFTAR RUJUKAN}

Al-Hafizh, M. (2016). Rasisme dalam Masyarakat Pascakolonial : Sebuah Analisis Wacana Kritis terhadap Novel-Novel Jacqueline Woodson. Humanus : Jurnal Ilmiah Ilmu-Ilmu Humaniora, 15 (2), 177- 194.

Amani, Natasha Khairunisa, (2020). Black Lives Matter Populer Saat Demo Kematian George Floyd, Ini Asal Mulanya. https://www.liputan6.com/global/read/ 4270455/black-lives-matter-populersaat-demo-kematian-george-floyd-iniasal-mulanya

Bardill, N. J. (2003). Dimensions of Racism: The international legal response to racism. Geneva: the Office of the United Nations High Commissioner for Human Rights (OHCHR) in cooperation with the United Nations Educational, Scientific and Cultural Organization (UNESCO).

BBC. (2020). www.bbc.com.

Boyle, K. (2003). Dimensions of Racism. the Office of the United Nations High commissioner for Human Rights (OHCHR) and the United Nations Educational, Scientific and Cultural Organization (UNESCO) (pp. 1-2). Geneva: Research and Right to Development Branch, AntiDiscrimination Unit Office of the United Nations High Commissioner for Human Rights. 
Bradley, A. S. (2019). Human Rights Racism. Harvard Human Rights Journal.

Boza, Tanya-Golash. (2016). A Critical and Comprehensive Sociological Theory of Race and Racism. ASA: American Sociological Association, 2 (2).

Charlina, R. (2017). Combating Cyber Racism: Analisis Komparatif terhadap Implementasi Protokol Tambahan Council of Europe Convention on Cybercrime tentang Cyber Racism (CETS 189) di Amerika Serikat dan Australia Tahun 2012-2016. Journal of International Relations, 41.

CNBC Indonesia. (2020). https://www.cnbcindonesia.com. Kata Siapa Rasisme Tak Berdampak Ke Ekonomi AS Ini Buktinya.

CNBC Indonesia. (2020). https://www.cnbcindonesia.com. $\quad D i$ Balik George Floyd Ada Ketimpangan Antara Si Hitam Putih.

Constitutions, U. (1992). First Amendement. U.S Goverment Information.

Deutsche Welle. (2020). https://www.dw.com. Diskriminasi Kulit Hitam di Amerika Serikat.

Frey, W. (2015). Explosion: How New Racial Demographics are Remaking America. Washington D.C.: Brookings Institution.

Fuchs, L. H. (1994). Kaleidoskop Amerika : Ras Etnik, dan Budaya Warga (Pen. R. Soeroso, Ed. Wilsom Nadeak. Bandung: Remaja Rosdakarya.

George Floyd, (2020). https://www.theguardian.com/usnews/george-floyd

Hooks, B. (1996). Killing Rage: Ending Racism. London: Penguin.

Human Rights and United States Law, https://www.theadvocatesforhumanrig hts.org

ICERD. (1969). International Convention on the Elimination of All Forms of Racial Discrimination.
Jismulatif. (2014). Studi Tentang Rasialisme dalam Film "The Green Mile". Ilmu Sejarah, Budaya dan Sosial.

Malik, A. K. (2016). Peranan Malcom X Dalam Perjuangan Hak-Hak Sipil Orang Kulit Hitam di Amerika Serikat Tahun 1957-1965. Perpustakaan Universitas Pendidikan Indonesia, 1-2.

Mappingpoliceviolence. https://mappingpoliceviolence.org. Black People are Most Likely to be Killed by Police.

Myrdal, G. (1944). An America dilemma: The Negro Problem and Modern Democracy. New York: Harper \& Brothers Publishers.

Nationalgeographic.

(2019). https://nationalgeographic.grid.id.

Tempat Terbaik Bagi Warga Kulit Hitam Afrika Amerika.

Nationalgeographic. www.nationalgeographic.grid.id.

Kematian George Floyd dan Sejarah Panjang Rasisme di Minneapolis.

Nations, U. (1945). Charter of the United Nations and Statute of the International Court of Justice. San Fransisco: United Nations Department of Public Information.

Sandra L.Colby and Jennifer M. Ortman. (2015). Projections of the Size and Composition of the U.S. Population: 2014 to 2060. New York: U.S. Census BUREAU.

Sloss, D. (2015). How International Law Transformed The U.S. Constitution. Human Rights Quarterly.

Sutopo, O. R. (2016). Rasisme dan Marginalisasi dalam Sejarah Sosiologi Amerika. Masyarakat Jurnal Sosiologi, 21 (2): $285-290$.

The Association for the Study of African American Life and History/ASALH. (2019). https://asalh.org. AfricanAmericans and the Vote. 
The Civil right Project, truthout.org. (2020). Truthout. What School Segregation Looks Like In The US Today.

Tod, Lewis paul dan Merle Curti. (1927). Rise of The American Nation. New York: Harcourt Brace.

UNESCO. (2015). Countering Online Hate Speech. UNESCO. Paris: United Nations Educational, Scientific and Cultural Organization Publishing.
UNHCR. (2009). Combating Racism, Racial Discrimination, Xenophobia and Related Intolerance Through A Strategic Approach. Geneva: United Nations High Commissioner for Refugees (UNHCR) Division of International Protection.

United States Census Bereau. (2020). www.census.gov. Ten Places With the Highest Percentage of Blacks or African Americans: 2010 